研究資料

\title{
運動部活動での外部指導者活用に向けた組織的実践の長所と問題点： 異なる実践モデルに対する教員の評価
}

\begin{tabular}{|c|c|c|}
\hline 健隆1),2) & 石井 香織1) & 柴田 \\
\hline 弘和 ${ }^{4)}$ & 花子5) & 岡 浩一朗1) \\
\hline
\end{tabular}

Kenryu Aoyagi ${ }^{1,2}$, Kaori Ishii ${ }^{1}$, Ai Shibata ${ }^{3}$, Hirokazu Arai ${ }^{4}$, Hanako Fukamachi ${ }^{5}$ and Koichiro Oka ${ }^{1}$ : Strengths and problems of organizational practice using an external coach for school-based extracurricular sports activities: Teacher's assessment of different practical models. Japan J. Phys. Educ. Hlth. Sport Sci. 60: 783-792, December, 2015

\begin{abstract}
School-based extracurricular sports activities are beneficial for positive youth development. However, there is a shortage of appropriate in-school coaches, and therefore recruitment of external coaches has been considered as one solution to this. A previous study has reported 4 model strategies of organizational promotion to recruit external coaches. These 4 models included "compensational support", "staff introduction", "delivery of collegiate students", and "cooperation with company". In order to promote the further development and popularization of these organizational trials, user-side evaluation is necessary. Therefore, the purpose of the present study was to clarify the strengths and problems related to these 4 organizational promotion strategy models when recruiting external coaches for schoolbased extracurricular sports activities from the viewpoint of teachers. The participants were 12 teachers who worked in public junior high or high schools. All of them had experience of coaching school-based extracurricular sports activities. Face-to-face semi-structured interviews were conducted with the individual participants, and all interview data were transcribed. Then, similar meaning units were grouped into themes with respect to the 4 models, strengths and problems. As a result, many specific themes for each model emerged. For instance, with regard to "compensational support", monetary support was regarded as a strength, although the early application period was a problem. With regard to "staff introduction", adequacy for beginners was a strength, but lack of mediation organization was a problem. With regard to "delivery of collegiate students", regular coaching was seen as a strength, but worry over not choosing a delivered external coach was a problem. With regard to "cooperation with company", high coaching skill was a strength, but an expensive coaching fee was a problem. Additionally, comprehensive opinions about all the models were reported, such as lack of information about the system and the need for educational coaching. These similarities and differences in the results indicated the importance of mediation system design considering the regionality and situation of the school-based extracurricular sports activity. Effective publicity and re-examination of financial manager is also needed.
\end{abstract}

1) 早稲田大学スポーツ科学学術院 ３59-1192 埼玉県所沢市三ケ島 2-579-15

2) 日本学術振興会 干102-0083 東京都千代田区夈町 5-3-1

3) 筑波大学体育系 于112-0012 東京都文京区大塚 3-29-1

4) 法政大学文学部 于102-8160 東京都千代田区富士見 2-17-1

5) 早稲田大学大学院スポーツ科学研究科 干359-1192 埼玉県所沢市三ケ島 2-579-15 連絡先 青柳健隆
1. Faculty of Sport Sciences, Waseda University 2-579-15 Mikajima, Tokorozawa, Saitama 359-1192

2. Japan Society for the Promotion of Science 5-3-1 Kojimachi, Chiyoda-ku, Tokyo 102-0083

3. Faculty of Health and Sport Sciences, University of Tsukuba

3-29-1 Otsuka, Bunkyo-ku, Tokyo 112-0012

4. Faculty of Letters, Hosei University 2-17-1 Fujimi, Chiyoda-ku, Tokyo 102-8160

5. Graduate School of Sport Sciences, Waseda University 2-579-15 Mikajima, Tokorozawa, Saitama 359-1192 Corresponding authorkenryu.aoyagi@gmail.com 
In addition, mediation organization and teachers should arrange previous meetings with external coaches to understand their human qualities and educational attitude. Furthermore, it would be valuable to develop the quality of external coaches through previous training or workshops. Finally, changes in the application period for each mediation system are suggested.

Key words : coach, volunteer, human resource management, interview キーワード：コーチ，ボランティア，人材管理，インタビュー

\section{1. 背 景}

我が国では近年, 中学生の $65 \%$ 以上, 高校生 の $40 \%$ 以上が運動部活動に加入し，運動やス ポーツに親しんでいる（笹川スポーツ財団, 2014). 概して運動部活動が青少年の心身の健全 発達にとって有益であるというこれまでの研究を 考慮すると（Farb and Matjasko, 2012)，今後も 充実した運動部活動を推進していく必要があると 言える。しかし，専門的に指導できる顧問の不足 や, 顧問の過大な負担などの部活動運営上の問題 点が指摘されている（文部省，1997；日本体育 協会，2014）。近年ではそれらの問題を解決する ため, 顧問の代わりや補助として運動部活動の指 導・運営を行う外部指導者の活用推進が求められ ている（文部科学省, 2010).

日本各地で外部指導者の活用推進のための様々 な取り組みが行われているが，青柳ほか（2015） は実施主体やシステムの異なる 11 組織の取り組 みを組織側の視点から事例研究的に明らかにして いる. また，それらの事例は特徵の類似性から4 つのモデルに類型化された（青柳ほか，2014）.

「(1)謝礼補助型」では, 都道府県教育委員会など が主体となって，すでに学校で活動している外部 指導者に対しての謝礼金の補助を行っている. 具 体的には, 学校から申請のあった外部指導者に対 して年間20回などの範囲の中で, 既定額（先行 研究の事例では， 1 回 2 時間で2,650円）の謝礼 金を支払う取り組みである。「(2)人材紹介型」で は, 学校からの依頼を受けた人材紹介組織が，求 める競技や条件に合った指導者を登録者の中から 選定して謝礼金が不要なボランティア指導者とし て学校に紹介するという，担当者が間に入って仲
介する方法が主である. また，データベース上に 登録者情報を公開し, 依頼者側の学校が条件に合 う指導者を決め, 組織の担当者がその登録者に連 絡する方法もある。「(3)学生派遣型」は, スポー ツ指導のボランティアを行いたい学生と外部指導 者を求めている近隣の学校を結び付ける取り組み である．学生に対しては，派遣前の事前研修や， 顧問からのフィードバックが提供されている. 最 後に「(4)企業連携型」では, 学校側が企業に月 2 回程度の指導者派遣を依頼する. 先行研究の事例 では, 指導料は 1 回部員 1 人につき 500 円に設定 されていた.

上述の各取り組みは現状でも一定の成果を上げ ているものの, 更なる改善や普及のためには先行 研究（青柳ほか，2014，2015）で対象とした組 織側だけでなく, 利用者側の視点からの検証が不 可欠である. 中でも制度や取り組みの利用を決定 する教員（顧問）の視点は欠かせない. 教員の視 点としては, 現在当該制度を活用している教員 と，現在は制度を活用していない教員という 2 つの視点の設定が可能であるが，本研究では特に 制度を今後広く普及していくという立場に立ち, 制度を外側から概観した意見を収集するため，後 者の教員に注目した。

以上より本研究の目的は, 先行研究 (青柳ほか, 2014）で報告されている 4 類型（1)謝礼補助型, (2)人材紹介型, (3)学生派遣型, (4)企業連携型) の 外部指導者活用推進の取り組みについて, 制度を 活用・選択する際に参考になる各モデルの長所 と, 制度の普及・改善に関わる問題点を, 教員の 視点から明らかにすることとした。 


\section{2. 方 法}

\section{1. 対象者}

質的研究のサンプルサイズについて, Guest et al.（2006）は，潜在的な意見の9 割程度は12名 に対するインタビューで抽出されることを示して いる. そのため, 本研究の対象者は公立の中学校 または高等学校に勤務する教員 12 名とした。対 象者の選定においては，偏りのない意見を収集す るため対象者の属性が多様になるように配慮し, 縁故法を用いて筆者らの知人教員を介した合目的 的なサンプリングを行った。内訳は男性が 7 名, 中学校教員が 6 名であり, 全員が運動部活 動の顧問経験を有していた。年齢は26歳から51 歳までが含まれ, 平均年齢は39.6歳（標準偏差 $=$ 8.1）であった。対象者は都市部（東京都）, 郊外 (神奈川県), 地方 (秋田県) と環境が異なる 3 つの都道府県単位の地域から選定された。詳細は 表 1 に示す。

\section{2. 手続き}

まず, 対象者に本調査の趣旨, 調査内容, 参加 は自由意志であること, 個人情報は厳守されるこ となどを説明し，文書による同意を得た。続いて， 1 対 1 の半構造化インタビューを実施した. その

表 1 対象者の特徵

\begin{tabular}{|c|c|c|c|c|c|}
\hline No. & 学校種 & 性 & 年歯令 & $\begin{array}{l}\text { 顧問経 } \\
\text { 験年数 }\end{array}$ & 主な担当種目 \\
\hline 1 & 中学校 & 男性 & 36 & 10 & サッカー \\
\hline 2 & 中学校 & 男性 & 40 & 18 & 軟式野球 \\
\hline 3 & 中学校 & 男性 & 47 & 23 & 軟式野球 \\
\hline 4 & 中学校 & 男性 & 47 & 24 & 陸上競技 \\
\hline 5 & 中学校 & 女性 & 28 & 6 & ソフトテニス \\
\hline 6 & 中学校 & 女性 & 46 & 24 & 水泳 \\
\hline 7 & 高校 & 男性 & 26 & 3 & 自転車 \\
\hline 8 & 高校 & 男性 & 38 & 16 & バスケットボール \\
\hline 9 & 高校 & 男性 & 45 & 23 & 剣道 \\
\hline 10 & 高校 & 女性 & 31 & 7 & バレーボール \\
\hline 11 & 高校 & 女性 & 40 & 15 & バスケットボール \\
\hline 12 & 高校 & 女性 & 51 & 28 & バスケットボール \\
\hline
\end{tabular}
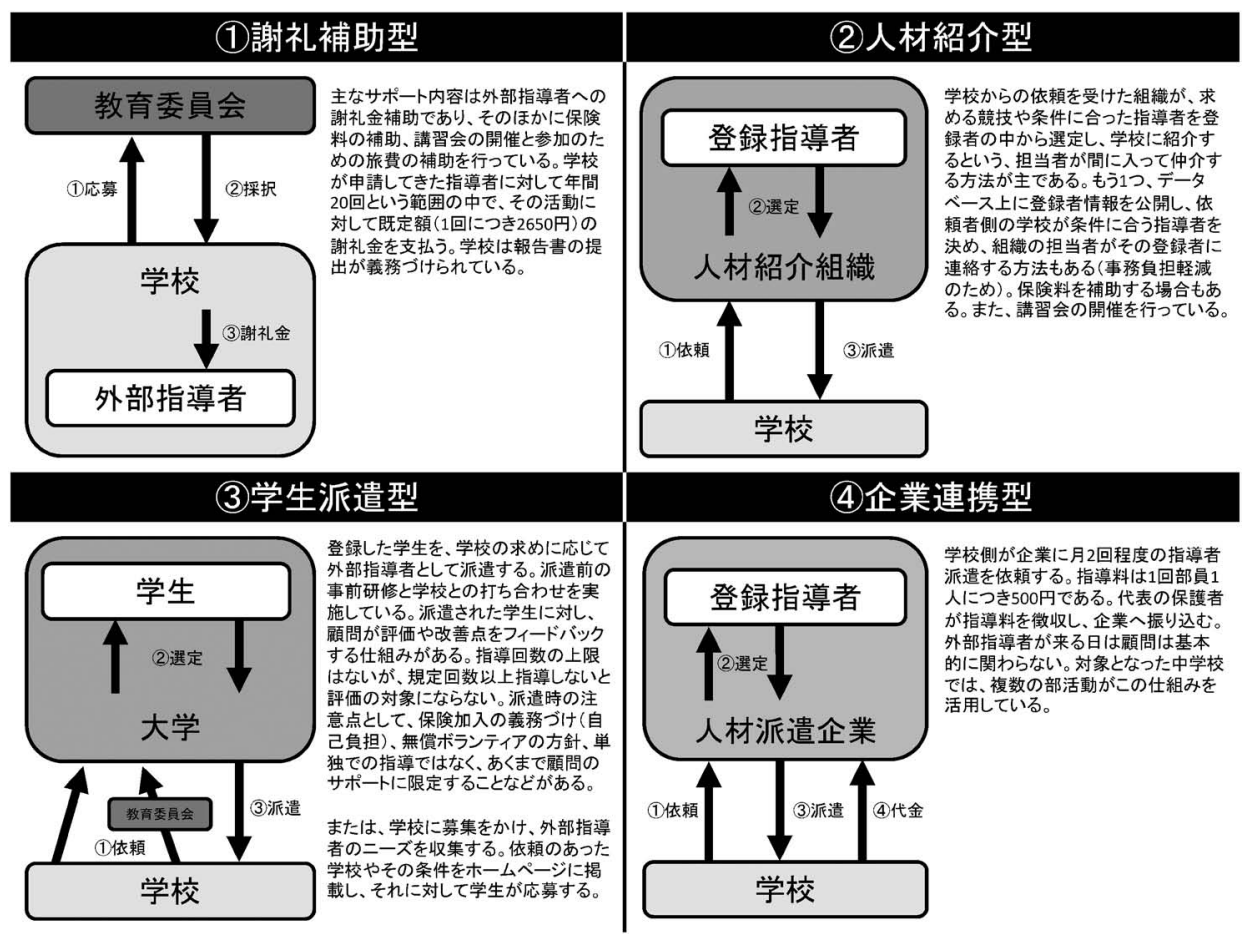

図 1 対象者に提示した 4 類型のモデルと説明文書 
際，はじめに 4 類型のモデル図と説明文書を記 した資料（図 1）を提示し，概要を説明すること で, 各モデルを具体的に想起させた。 その後, 各 モデルを比較した際のそれぞれの長所や問題点に 関するオープンエンドの質問を，会話展開に合わ せて意見が出尽くすまで行った.

すべてのインタビューは, 対象者の交通の便が 良い場所（教員が勤務している学校の会議室等） で実施した、調査実施にあたり，事前に早稲田大 学の「人を対象とする研究に関する倫理委員会」 の承認を得た（申請番号2014-066）。調查期間は 2014年 7 月から 2014 年 8 月までであった.

\section{3. 分析}

録音したインタビュー内容はすべて逐語化し， 逐語録を作成した。はじめに逐語録を熟読し，1 つの意味を表していると考えられる意味単位を抜 き出してカード化した，続いて，逐語録の文脈も 考慮しながら，それぞれの意味単位が 4 類型の どのモデルについて言及しているかによって 4 つに振り分けた。 また，複数のモデルについて言 及している意味単位（例えば，「(1)と（2)は○○で ある.」）についてはカードを複製し，両モデルに それぞれカードを残した，その後，モデルごとに 類似する内容を表していると考えられる意味単位 を集約し，意味単位（生データ）の内容を一言で 表すテーマを作成した。最後に，テーマを長所お よび問題点に分類した. 分析の妥当性を高めるた め, 直接研究に関係しない研究者に各テーマへの 意味単位の分類が適切か意見を聴取した（ピアデ ィブリーフィング ; フリック，2011）。異議があ る場合には，合意が形成されるまで議論し，最終 的な分類を決定した. また, 研究手法を熟知する 研究者に分析の初期段階から最終段階に至るま で，適宜確認を依頼した（スーパーバイズ ; 瀬畠 ほか，2001)。

\section{3. 結 果}

ここでは各モデルの長所と問題点に関するテー マを表 2 にまとめ,それぞれのモデルの詳細な 説明を行う。以下文中では，集約されたテーマを
【】内に，対象者の具体的な回答を「」内に 示し, 筆者の発言や補足を（）内に記述する.

\section{1. (1)謝礼補助型に関する内容}

長所として【打金がかからないこと】【教育 委員会と連携していること】,【もともと知ってい る人が外部指導者だと安心感や信頼性が高いこ と】が挙げられた。中学校の女性教員からは, 「やっぱり金銭的なところが一番心配．なぜなら ば，学校納金や給食費もなかなか滞っているご家 庭も多く, 昔のようにですね, 経済的に負担が大 きくて払えないというよりも，塾とかスマホの月 何万っていうのを払っても, 学校納金は後回しに するっていう家庭がちょっと増えてる感じなん で，打金がかかるこういう部活動に対しては，保 護者はどうなんだろうなっていうのはちょっと 今, やったこともないので, ちょっとこう疑問っ ていうか. となると, 学校ではなるべくその保護 者からの集金っていうのに，あまり携わりたくな いっていうのが本音なんで.」といった保護者か らの集金にはあまり関わりたくないという意見が 聞かれた。 また，ある教員（高校・男性）は「(1) のやつは, もともと学校の関係者がその外部指導 者の人を知ってて，この人にやってもらいたいか ら，こういう形でやる。で，そういう人がいれ ば，こういう形が一番手っ取り早いし，安心感が あるんじゃないかなと思う.」と述べるように， 謝礼補助型だけはもともと部活動にいる外部指導 者であり，新規に派遣してもらうわけではないた め安心感があるということであった。

問題点としては, 【活動量と謝礼が比例してい ないこと】、【補助が一部のみ，または上限がある こと】、【申請時期が早いこと】,【制限回数以上関 わることにより顧問と外部指導者の方針の不一致 が起こる場合があること】、【外部指導者が見つか らないこと】、【報告書の負担が大きいこと】、【制 度上の制限が多いこと】が報告された．以上のよ うに，予算の関係上，謝礼金額や指導回数が限ら れていることに不満を抱いていた。 ある教員（高 校・女性）は，類似の制度について「3 月の末に 決めておかないといけないんですよ。いることが 前提で．学校で調整をするから．ある程度目星が 
表 2 各モデルの長所と問題点に関するテーマ

\begin{tabular}{|c|c|c|}
\hline & 長所に関するテーマ & 問題点に関するテーマ \\
\hline $\begin{array}{l}1 \\
\text { 謝 } \\
\text { 礼 } \\
\text { 補 } \\
\text { 助 } \\
\text { 型 }\end{array}$ & $\begin{array}{l}\text { ・お金がかからないこと } \\
\text { ・教育委員会と連携していること } \\
\text { ・もともと知っている人が外部指導者だと安心感や信 } \\
\text { 頼性が高いこと }\end{array}$ & $\begin{array}{l}\text { ・活動量と謝礼が比例していないこと } \\
\text { ・補助が一部のみ，または上限があること } \\
\text { ・申請時期が早いこと } \\
\text { ・制限回数以上関わることにより顧問と外部指導者の } \\
\text { 方針の不一致が起こ場合があること } \\
\text { ・外部指導者が見つからないこと } \\
\text { ・報告書の負担が大きいこと } \\
\text { ・制度上の制限が多いこと }\end{array}$ \\
\hline $\begin{array}{l}\text { (2) } \\
\text { 人 } \\
\text { 材 } \\
\text { 紹 } \\
\text { 型 } \\
\text { 型 }\end{array}$ & ・初心者の部員向けであること & $\begin{array}{l}\text { ・ 申請時期が早いこと } \\
\text { ・紹介された外部指導者に教育者としての資質がある } \\
\text { が不安かるこ } \\
\text { ・過度に勝利や技能の向上を目指すイメージがあり, } \\
\text { 指導理論の押しつの可能性があること } \\
\text { ・紹介される外部指導者を選べない不安があること } \\
\text { ・ボランティアの善意に頼るため, 継続性に不安があ } \\
\text { ること } \\
\text { ・人材紹介組織がないこと }\end{array}$ \\
\hline $\begin{array}{l}\text { (3) } \\
\text { 学 } \\
\text { 生 } \\
\text { 派 } \\
\text { 遣 } \\
\text { 型 }\end{array}$ & $\begin{array}{l}\text { ・部員と一緒にプレーしてくれるイメージがあること } \\
\text { ・部員教育と学生教育という目的が一致していること } \\
\text { ・部員と近い目線で指導してくれるイメージがあること } \\
\text { ・お金がかからないこと } \\
\text { ・定期的に来てくれるイメージがあること }\end{array}$ & $\begin{array}{l}\text { ・紹介される外部指導者を選べない不安があること } \\
\text { ・学生という立場に指導への不安があること } \\
\text { ・学生派遣組織がないこと }\end{array}$ \\
\hline $\begin{array}{l}\text { (4) } \\
\text { 企 } \\
\text { 業 } \\
\text { 連 } \\
\text { 䇰 }\end{array}$ & $\begin{array}{l}\text { ・謝礼が高いわけではないこと } \\
\text { ・企業が管理している人材のため, 信頼できること } \\
\text { ・謝礼を払っているため, 責任を取ってくれるイメー } \\
\text { ジがあること } \\
\text { ・本物に触れられること } \\
\text { ・企業と学校の利害関係が一致していること } \\
\text { ・指導力が高いこと } \\
\text { ・技術指導以外の人材もいること }\end{array}$ & $\begin{array}{l}\text { ・抢金がかかること } \\
\text { ・指導頻度が少ないこと } \\
\text { ・生徒指導ができないイメージがあること } \\
\text { ・教育委員会と連携していないこと } \\
\text { ・紹介された外部指導者に教育者としての資質がある } \\
\text { か不安があること } \\
\text { ・人材派遣企業がないこと } \\
\text { ・紹介される外部指導者を選べない不安があること }\end{array}$ \\
\hline
\end{tabular}

付いてないと, 登録してやっぱり見つからなかっ たので駄目ですと言うと，学校が困っちゃうとい う話になるので.（なるほど.ちょっと難しいな と思うのは, 先生方がちょうど 3 月に異動する 場合があるじゃないですか.だとすると，何かこ うミスマッチがあるような気がして.）そういう ことも出てくるかなって思いますね. ちょっと逆 にずらす，例えば 4 月の時点で新しく始まって， 5月からとかっていうふうにできるんだったら ね. そのほうがいいですよね.」と述べ, 申請時 期が前年度であるよりは当該年度であるほうが良 いことが指摘された。

\section{2. (2)人材紹介型に関する内容}

人材紹介型の長所として, ほかのモデルよりも 比較的,【初心者の部員向けであること】が挙げ られた。高校の男性教員は「(2)は，打金はかから ないっていうことかな. 何かボランティアみたい な形だよね. そうすると, 例えばこうマイナース ポーツで, 部活があるけど指導者がいなくて, 導 入の段階でちょっとそういう指導者に来てもらい たいなぐらいのときは，こういうボランティア型 みたいのがいいかもしれない，とりあえずこう， きっかけを.きっかけっていうか, 初心者に教え てもらう.」と述べていた。

問題点としては, 【申請時期が早いこと】, 【紹 
介された外部指導者に教育者としての資質がある か不安があること】、【過度に勝利や技能の向上を 目指すイメージがあり, 指導理論の押しつけの可 能性があること】,【紹介される外部指導者を選べ ない不安があること】,【ボランティアの善意に頼 るため, 継続性に不安があること】,【人材紹介組 織がないこと】が報告された。 中学校の男性教員 が類似する制度について，「人材紹介型は，年間 計画で来るんです。この日にこの人空いてますよ ってバッと来て. 去年の例だと, 確かそれ 11 月 ぐらいにもらってんですよ，来年の分で．ただ, それもらっていて，申し込反も，その去年のうち にやらなきゃいけないんですけど，ただ異動する かもしれないじゃないですか. 異動して, 何か結 局，あとの人よろしく初ていうのもできないの で，ちょっと躊躇しちゃうんですよね.または， 部活変わってしまう可能性もあるんで．だから， そこはちょっと難しいかなというふうには思って ますね，引き継ぎの問題ですね，要は．その申し 込む期間が，またずれれば，例えば新年度になっ てからっていうふうになれば，また違ってくると 思います.」と述べるように，申請時期について は謝礼補助型と同様，前年度に申請しなければな らないことに活用しづらさを感じていた。 そのほ か，「われわれはやっぱり教育の一環で部活動っ てやるんで，教育者としての資質が，こういうふ うな方々はどこまで備わってるのかなっていう心 配はあるかもしれない。そういう，何かこう研修 っていうか，教育的な指導っていうか，そういう のをしっかりやってくれてるような指導者であれ ば，利用したいなとは思うんですけど。（高校· 女性)」や「実際に難しいのは，人間関係だった り, 顧問とのその関係性たっったり, 生徒との関係 性だったりを考えたときに，ある程度知ってる人 間だと，こっちは雇いやすい。まあ， 1 年間とい う契約になっちゃうから，雇いやすいけれども， いきなりこういう形で来られたり, 学生にしても どんな学生が来るかわかんないという状態だと, やっぱり結構，困るなというとこはありますね. (高校・女性)」など, 教育的な資質や外部指導者 を選べないことに対する不安に関する内容が多く
認められた。

\section{3. (3)学生派遣型に関する内容}

長所として、【部員と一緒にプレーしてくれる イメージがあること】、【部員教育と学生教育とい う目的が一致していること】【部員と近い目線で 指導してくれるイメージがあること】，【打金がか からないこと】、【定期的に来てくれるイメージが あること】が挙げられた。学生派遣型に対して は，「ただ教えたいっていう意欲と，学びたいっ ていう子どもたちのマッチが見えるといいなと. (中学校・男性)」や「将来教員になりたい学生と かであれば，なおさら，修行の場として考えるん であればいいのかなと.(中学校・男性)」という 部員と学生双方にとって恩恵や教育的意義がある 関わりが望まれていた。 また，中学校の男性教員 の「学生だとたぶんね, これ，一緒にやってるん だよ。一緒にやる。僕はまだ一緒にやるイメージ がある. 大学生, 経験者だから. 野球を経験して きて，野球を指導をしていく上で，一緒に手伝っ てくれる人がいればいいわっていう感覚で話して る.」という意見からは，部員と一緒になってプ レーするような関わり方を求めていることがわか る.加えて，「平日も来ていただけるのは，何か (3)のような気がするんですね.やっぱり外部指導 者の方って，ほかの仕事も持っていると思うんで すよね，当然（中略）平日に来ていただけるの は(3)ってう感じですかね. 比較的学生のほう が，放課後とかそういうのもありますんで，来て いただける，継続して見ていただけるっていうん であれば，(3)もりかなっていう感じですね.」 という教員（中学校・男性）がいるように, 学生 には頻度の高い関わりを期待していることが示唆 された。

問題点としては,【紹介される外部指導者を選 べない不安があること】,【学生という立場に指導 への不安があること】、学生派遣組織がないこと】 が報告された。学生という立場の長所の反面, 「学生のほうなんですけども，まあこれは，あり かなというところもあるんですけども，ただちょ っとその，生徒との年齢が近いっていうこともあ って，指導が届くのかなっていう，ちょっと不安 
な要素がありますね. (中学校・男性)」や「どこ まで子どもたちのことをわかってやってくれるの かっていう不安とかはあります。自分が学生だっ たときももちろんあったんで，そこまで責任をも って, 例えばケガとか, 夏だったらもう熱中症に なっちゃうからっていうそういう危険とか，そう いうのも全部考えてやってくれんのかなとか，ど こまで責任をもってやってくれるのかなってい う, ちょっと不安とかっていうのも感じます. (中学校・女性)」という発言からは, 部員との年 齢の近さ, 責任感の乏しさなどに起因する不安を 感じていることが推察される.

\section{4. (4)企業連携型に関する内容}

長所として,【謝礼が高いわけではないこと】,

【企業が管理している人材のため, 信頼できるこ と】，【謝礼を払っているため，責任を取ってくれ るイメージがあること】、【本物に触れられるこ と】,【企業と学校の利害関係が一致しているこ と】，【指導力が高いこと】,【技術指導以外の人材 もいること】が挙げられた。これらから, 企業連 携型に対してはより専門性の高い指導を求めてい ることが示唆された。 また, 高校の男性教員は 「1回500円っていうのはさ, どうなの? 月 2 回だ から1,000円でしょう? 普通それまでかけた月謝 考えれば，高くはないよな.」また「お金さえち ょっと出せばできるような何かシステムがあった ほうが，逆に入りやすいよう気するな.ちょっと した，ほら，スポーツクラブに行くような感覚で さ。（中略）俺学生のときにフィットネスクラブ でバイトしてたもんな. そうすると, 会員の人っ て1回何千円か払って，わざわざ体動かしに来 るじゃない，俺ああいう感覚でもいいと思うんだ よな.」と述べ，ほかの習い事などの月謝やスポー ツクラブに通わせることを考えると，1 か月に 1,000円という金額はそれほど高くないと考えて いた.【技術指導以外の人材もいること】に関し ては,「競技の指導というよりは, ウエイトトレー ニングとか, 栄養指導とか, あとメンタルトレー ニングとか，そういうのの講習をやってもらえた らいいなとは思う。(高校・男性)」という意見が 挙げられた。
しかし，【打金がかかること】は多くの教員が 指摘している問題点であった. ある高校の女性教 員は「例えば 30 人って， 25 人をではオーケーだ けど，その 5 人が払えないとか，払わない招子 さんがいる場合に，部活をどうやって成り立たせ るか難しいですよね.」と述べていた。 また，そ れ以外の問題点として,【指導頻度が少ないこ

と】、生徒指導ができないイメージがあること】,

【教育委員会と連携していないこと】,【紹介され た外部指導者に教育者としての資質があるか不安 があること】、【人材派遣企業がないこと】、【紹介 される外部指導者を選べない不安があること】が 報告された，たとえ企業が派遣する人材であった としても，「(4)は本当に技術的なものは，すごい 高いとは思うんですけども，その月に 2 回しか 呼べないってことは，30日中 2 日しか見れない っていうことなので，子どもを教育する上で，そ の場面だけしか見れないっていうのがちょっと, 難点かなっていうのがありますね. まあ技術的な ものだけであればいいんですけども，ちょっとそ れ以外の, 生徒指導とかのそういう要素もあると 思うんで，これはちょっと難しいかなっていうの と. (中学校・男性)」や「登録指導者を自分で選 べないっていうのも, ちょっと不安もあります。 (中学校・女性)」という意見からは, 教育面やど のような指導者が派遣されるかわからないことに 対する不安が大きいことが読み取れる.

\section{5. 全体に関する内容}

本研究の主目的ではないが，それぞれのモデル に関する意見ではなく, 全体を俯瞰した意見もい くつか報告された．指導者紹介情報の不足に関し て，「近くにさっき大学があるって言ったけど, そういう人材紹介も, どこにこう, 紹介してもら ったらいいんだろうとか, どこの企業をこう, や ったらいいんだろうみたいなのが，あんまりこう 浸透してない。まあ, たぶんあるんだろうけど， ホームページとかには. (高校・男性)」などのよ うに，どこでそのような制度の情報を得られるか わからないといった意見が多く見られた．また， ある高校の女性教員の「なんだかんだ言っても部 活っていっても, 技術だけじゃなくてやっぱり人 
なんですよね. 部活動っていうのは，ただ勝てば いいっていうんじゃなくて，人間を育てる一環な んだよと、教育活動の一環なんだよっていうこと を，ちゃんと理解してくれる人．そういう人材が ほしい。ただ技術があるだけじゃなくて.」とい う意見が代表するように，技術面だけではない教 育的な指導を求めていた.

制度の改善に関するアイデアとして, 各モデル の併用が挙げられた。例えば, 人材紹介型, 学生 派遣型のいずれかで人材を紹介してもらい，謝礼 補助型の仕組みを利用して謝礼金を確保する方法 などである．また，中学校の男性教員の「本当は 一番いいのは, 俺は教師が習って, 教師が勉強し て, 教師が生徒には直接教えるの, 教師が直接教 えるのが，一番学校としては，教育という観点か らは, ベストじゃないかなっていう気はするんで すね.だからそこに，教師のコミュニケーション 能力が問われるのであって，ここになると，その 子の生い立ちとか, やっぱりあくまでもそこに教 師がちゃんと介在して，その子の家庭とか，いろ んなのを考えて, 学校の様子とか, それを考えて, 一番前面は教師であるべきなんじゃないかなっ て，中学校の場合はですね.」という意見からは， 教育の観点から考え, 外部指導者に部員への指導 を依頼するのではなく, 外部指導者から顧問が指 導法を学べばよいという考えの教員もいることが 示された. あるいは, 部活動の競技レベルによっ て人材源を使い分けるという発想も見受けられ た. 対象者からは, 競技レベルの低いチームには 人材紹介型, 外部指導者との切硣环磨によって部 員の技能を引き上げたい場合には学生派遣型, さ らなるレベルアップを求める場合には企業連携型 といった活用例が挙げられた.

\section{4. 考 察}

本研究では, 先行研究（青柳ほか, 2014）で 分類された 4 類型（1)謝礼補助型，(2)人材紹介 型, (3)学生派遣型, (4)企業連携型) の外部指導者 活用推進の取り組みについて，利用する側である 教員の視点から長所や問題点を探索することを目
的とし，インタビュー調査を実施した。 その結 果, 各モデル固有の長所および問題点が明らかに なり, 加えて, 制度全体に関する意見や改善案が 報告された. また本研究では, 制度を今後広く普 及していくことを目指して，現在は制度を活用し ていない教員を対象としたが，類似する制度の活 用経験のある教員からは, 制度の内面に関する具 体的な意見も出された.

人材紹介型, 学生派遣型, 企業連携型のいずれ に颃いても, 近隣に該当する組織がないという地 域性に関わる問題点が示された。教育委員会は各 都道府県, 各市区町村をほぼ網羅している組織だ が，大学や人材派遣企業は都市部などでなければ 移動可能圏内に存在しない場合もある. 外部指導 者の活用推進に取り組むうえでは, 大学や人材派 遣企業との連携が望める地域かどうかを考慮して 制度を設計していく必要がある。一方, 仮に組織 があったとしても, 教員がその存在を認知してい ない可能性も考えられる. 実際に情報の不足を訴 える教員が複数存在したことから, 制度を設ける 際は，学校や教員への広報を併せて進めていくこ とが不可欠である.

金銭面について，謝礼金が発生するモデルに対 して否定的な意見が多く認められた. 先行研究に 抢いて学校と外部組織の連携の阻害要因として予 算の不足が指摘されているように（高橋・杉原， 2006 ; Williams et al., 2011)，学校現場に抢いて 予算を捻出するのは容易ではないようであった. 特に, 企業連携型に関しては全部員の保護者の同 意がなければ依頼することが難しいことが報告さ れ，合意形成がなされないまま進めてしまうと部 活動に参加できない部員が出てしまう可能性があ る. また, 本研究の対象となった教員からは保護 者からの集金に関わりたくないという意見もあ り，謝礼金を支払いたくないということではな く，予算を捻出するための労力が大きな障害にな っていると推察される. 予算の捻出については顧 問に任せるのではなく, 学校や教育委員会などの 組織が支援をたは担当することで, 教員の負担が 軽減されると考えられる.

本研究の対象となった教員の多くは, 外部指導 
者の教育的指導力を不安視していた．そのため, 社会経験等の比較的少ないであろう大学生につい ては, 特に強い不安を抱いていた。 もともと部活 動にいる外部指導者に謝礼を支払う謝礼補助型に ついてはそのような意見が出なかったことから， 外部から紹介される人材全般に対して, 教育面に 関する不安があることがわかる，これは先行研究 (Aoyagi et al., 2013) で示された，教員が外部指 導者に対して教育的思考を求めていることを支持 する結果である。 また, 人材紹介型, 学生派遣 型, 企業連携型のいずれに扔いても紹介される外 部指導者を選べない不安があることが問題点とし て挙げられていた，派遣する指導者を選定する 際, 学校の求める競技や条件に合うという選定基 準だけでは, 外部指導者の人間性までは判断でき ずに不安が残るものと考えられる。外部指導者を 採用する際は，外部指導者々顧問の間で面談を実 施し, 学習指導要領（文部科学省，2008，2009） に示されているように, 部活動が学校教育の一環 であることを了承してもらったうえで受け入れる ことで, 採用後のトラブルを未然に防ぐことがで きると考えられる，また，例えば東京都教育委員 会（2008）の「外部指導員のための部活動指導 の手引」や鹿屋体育大学学生スポーツボランティ ア支援室（2012）の「学生スポーツボランティ ア指導者ガイドブック」などを参考に, 派遣前の 事前学習や指導者講習会等で外部指導者の資質を 高めていくことも重要である.

制度と学校現場との不調和として, 人材紹介や 謝礼金交付の申請時期に関する意見が挙げられ た. 公立学校の教員の場合, 定期的な人事異動が あるため, 前年度に次年度分の申請を求められる と申請を躊躇してしまう場合があるという．類似 した問題点として, 先行研究（青柳ほか, 2014） では予算交付時期の遅さも指摘されている. その ため, 制度策定側には申請時期を当該年度の初め に設定し，申請に対する迅速な人材紹介や予算交 付を行うなどの対応が望まれる.

本研究の限界点として，3地域のみの教員を対 象としたことが挙げられる. そのため, 本研究結 果の応用の際は, 教育行政や環境の地域差に留意
することが必要である.しかし， 3 地域の選定に あたっては都市部, 郊外, 地方と環境が異なる地 域を選定し, 縁故法を用いて対象者の属性が多様 になるように配慮したことで, 可能な限り偏りの ない意見の収集に努めたことを付記する.

対象者からは, 地域, 競技に関する教員自身の 専門性, 部活動の競技レベルなどによって異なる モデルを求める傾向が認められた. 1 つのモデル だけでなく, 複数のモデルの良い面を併用すると いうアイデアも示されたことからも, 既存の枠組 みにとらわれるのではなく, 部員や顧問にとって どのような制度が求められているのか, 今後も引 き続き検討していく必要がある。

\section{5. まと め}

本研究では, 教員に対してインタビューを行 い, 現在行われている 4 種類の外部指導者の活 用推進に関する取り組みの長所と問題点に関する 意見を聴取した、その結果, 各モデルへの個別の 意見のほか, 全体を俯瞰した意見も示された、こ れらの共通する部分や異なる部分の検討から, 地 域性や運動部活動の状況を考慮した制度の設計と 広報の必要性, 金銭管理の担当者の再検討, 指導 者との面談等による人間性理解と教育的指導の重 視, 派遣前の事前学習や指導者講習会による外部 指導者の資質向上, 制度への申請時期の見直しが 提案された. 相対的には, 学校側に金銭的な負担 が少なく, 教員志望の学生による教育的な関わり が望める学生派遣型に対する期待が大きいようで あった。しかし，あくまでも調査者の主観による 仮説に留まるため, 定量的な調査等によって検証 していくことが今後の課題であろう.

\section{付記}

本研究の一部は, 平成 26 年度科学研究費助成 事業（特別研究員奨励費, 課題番号 : 26 - 3450) および平成 27 年一 31 年度文部科学省私立大学戦 略的研究基盤形成支援事業（S1511017）の補助 を受け実施したものである. 


\section{文献}

Aoyagi, K., Ishii, K., Shibata, A., Arai, H., Hibi, C., and Oka, K. (2013) Factors associated with teachers' recruitment and continuous engagement of external coaches in school-based extracurricular sports activities: A qualitative study. Adv. Phys. Educ., 3 (2): 6270.

青柳健隆 - 石井香織 - 柴田 愛 - 荒井弘和 - 岡浩一朗 （2014）運動部活動での地域人材活用におけるモデル ケース比較分析. SSF スポーツ政策研究, 3(1): 257-264.

青柳健隆 · 石井香織 - 柴田 愛·荒井弘和 · 岡浩一朗 （2015）運動部活動での外部指導者活用推進に向けた 組織の取り組反事例。体育学研究, 60(1): 267-282.

Farb, F. A. and Matjasko, L. J. (2012) Recent advance in research on school-based extracurricular activities and adolescent development. Dev. Rev., 32: 1-48.

フリック, U. : 小田博志監訳 (2011) 質的研究入門. 春秋社, p. 477.

Guest, G., Bunce, A., and Johnson, L. (2006) How many interviews are enough?: An experiment with data saturation and variability, Field Method., 18(1): 59-82.

鹿屋体育大学学生スポーツボランティア支援室 (2012) 学生スポーツボランティア指導者ガイドブック．鹿 屋体育大学学生スポーツボランティア支援室.

文部科学省 (2008) 中学校学習指導要領. 東山書房, p. 19.

文部科学省 (2009) 高等学校学習指導要領. 東山書房, p. 23 .

文部科学省（2010）スポーツ立国戦略一スポーツコミ ュニティ・ニッポン一. http://www.mext.go.jp/a_ menu/sports/rikkoku/1297182.htm，（参照日2015年 6 月 16 日).

文部省（1997）運動部活動の在り方に関する調査報告. http: / / www.mext.go.jp / b_menu / shingi / chousa / sports / 001/toushin/971201.htm，（参照日2015年 6 月16日).

日本体育協会 (2014) 学校運動部活動指導者の実態に 関する調查報告書. www.japan-sports.or.jp/Portals/ $0 /$ data/.../doc/houkokusho.pdf, （参照日2015年 6 月 16日).

笹川スポーツ財団（2014） スポーッ白書一スポーッの 使命々可能性一. 笹川スポーツ財団.

瀬畠克之 ·杉澤廉晴 - 菊池優子 (2001) 質的分析に分 析者が抢よぼす影響に関する考察一質的データ分析 をどのように進めるか一。保健医療社会学論集, $12(2): 60-71$.

高橋幸加・杉原素子 (2006) 通常の学級の教員と保健 医療専門職との連携システムの構築関係 : 地域独自 の取り組反について。 日本保健科学学会誌, 9(3): 185-193.

東京都教育委員会 (2008) 外部指導員のための部活動 指導の手引. http: // www.kyoiku.metro.tokyo.jp / press/bukatsu_tebiki.pdf, (参照日2015年 6 月16日).

Williams, J. B., Hay, J. P., and Macdonald, D. (2011) The outsourcing of health, sport and physical educational work: A state of play. Phys. Educ. Sport Pedagog., 16 (4): 399-415.

$\left(\begin{array}{l}\text { 平成 } 27 \text { 年 } 6 \text { 月 } 17 \text { 日受付 } \\ \text { 平成 } 27 \text { 年 } 9 \text { 月 } 1 \text { 日受理 }\end{array}\right)$

Advance Publication by J-STAGE Published online 2015/10/2 